\author{
Krzysztof Jajko \\ Uniwersytet Łódzki
}

\title{
Nadmiar na sprzedaż: wstęp do opisu paradygmatu kina blockbusterowego
}

Współczesne kino blockbusterowe rozpatrywane wyłącznie z perspektywy instytucjonalno-ekonomicznej jest zjawiskiem o dość łatwych do zidentyfikowania właściwościach organizacyjnych. Świadczy o tym zbieżność wniosków, do jakich dochodzą liczni opisujący ten fenomen badacze ${ }^{1}$. Zasadniczo zgodzić można się z Marcinem Adamczakiem, który wymienia siedem podstawowych wyróżników kina blockbusterowego: system gwiazd, sequele, strategia superprodukcji, merchandising, publicity i pseudowydarzenia, strategia nalotu dywanowego oraz wykorzystanie różnych kanałów dystrybucji ${ }^{2}$. Należy przy tym zauważyć, że o ile pięć pierwszych zjawisk stanowi przedłużenie praktyk stosowanych już w erze klasycznego Hollywood, o tyle dwa ostatnie sa oznaką przemian, jakie zaszły $\mathrm{w}$ amerykańskim przemyśle filmowym na przestrzeni ostatnich 30 lat. Strategia nalotu dywanowego, a więc jednoczesnej prezentacji filmu w dniu premiery w ogromnej ilości kin, wyparła stosowany do połowy lat siedemdziesiątych, z biegiem czasu coraz mniej efektywny, model roadshow (otwarcie w małej ilości droższych kin pierwszej kategorii, gdzie filmy prezentowane były nawet przez kilka miesięcy zanim trafily do powszechnej dystrybucji), zaś wykorzystanie różnych kanałów rozpowszechniania, takich jak telewizja kablowa czy rynek kina domowego, puściło w niepamięć dawne wojny toczone pomiędzy przemysłem filmowym a przemysłem telewizyjnym o dominacje na rynku rozrywki (wraz z poczatkiem lat dziewięćdziesiątych ukształtował się nowy system medialnych konglomeratów, zrzeszających w swych szeregach różne sektory przemysłów rozrywkowych, na czele z korporacjami Time Warner oraz Disney).

\footnotetext{
${ }^{1}$ Spośród licznych publikacji wymienić tu należy książki autorstwa Sheldona Halla oraz Steve'a Neale'a Epics, Spectacles and Blockbusters, Detroit 2010 oraz Arthura De Vany Hollywood Economics: How Extreme Uncertainty Shapes the Film Industry, London-New York 2004, a także artykuł Thomasa Shatza The Studio System and Conglomerate Hollywood, [w:] The Contemporary Hollywood Film Industry, eds. Paul McDonald, Janet Wasko, Hoboken, NJ 2008.

${ }^{2}$ Marcin Adamczak, Globalne Hollywood, filmowa Europa i polskie kino po roku 1989, Gdańsk 2010, s. 29-74.
} 
Podczas gdy identyfikacja fenomenu współczesnego kina blockbusterowego z perspektywy przemian instytucjonalno-ekonomicznych nie przysparza większych trudności, próba spójnego opisu tego zjawiska na poziomie tekstualnym nie przedstawia się już tak bezproblemowo. W ciagu ostatnich kilkudziesięciu lat na obszarze filmoznawstwa zaproponowano kilka interpretacji, zmierzajacych do rozpoznania estetycznej dominanty hollywoodzkiego blockbustera. Pierwsza z nich, która można określić mianem „interpretacji historycznego powrotu”, wykazuje, że kino blockbusterowe poprzez zamiłowanie do epatowania widza spektaklem, w postaci niemajacych końca sekwencji przepełnionych widowiskowymi wybuchami oraz efektami specjalnymi, stanowi przedłużenie kina atrakcji, a więc opisanej przez Toma Gunninga, dominujacej tendencji we wczesnych latach funkcjonowania medium filmowego. Jak zauważa Thomas Elseasser, do upowszechnienia się tej bardzo wpływowej w kręgach filmoznawczych paraleli przyczynił się sam Gunning, wielokrotnie sugerujący w swych artykułach, że spektakularne hollywoodzkie superprodukcje z przełomu lat siedemdziesiątych i osiemdziesiątych, czyli zgodnie z jego nazewnictwem kino efektów Speilberga, Lucasa i Coppoli, w pewnym sensie maja swe korzenie w filmikach Edisona, braci Lumière oraz Mélièsa ${ }^{3}$.

Drugie z wyjaśnień, nazwijmy je „interpretacja historycznego zerwania”, dowodzi, że kino blockbusterowe ostentacyjnie odrzuca paradygmat kina klasycznego Hollywood, w którego centrum stoi zasada opowiadania spójnej historii napędzanej przez jasno zdefiniowane cele i dążenia głównego bohatera. Jak dowodzą zwolennicy tej opcji, współczesne kino hollywoodzkie spycha bohaterów na drugi plan, eksponując zamiast tego akcję oraz czystą wydarzeniowość. Dlatego takiego znaczenia nabiera opisana przez Justina Wyatta strategia high concept, a więc dążenia do oddania zawartości filmu za pomoca jednego, zwięzłego zdania, które potem może zostać wykorzystane jako chwytliwe hasło w kampanii reklamowej ${ }^{4}$. Konsekwencja takiego podejścia do produkcji filmów jest ich fabularna schematyzacja oraz rozrost widowiskowych sekwencji audiowizualnych, w postaci scen z dużą ilością efektów specjalnych albo dominacją teledyskowej estetyki.

Tym dwóm pierwszym opisom kina blockbusterowego wyraźnie sprzeciwia się „interpretacja historycznej ciagłości”, której wyrazicielami sa czołowi badacze szkoły neoformalno-kognitywnej, David Bordwell i Kristin Thompson. Wykazuja oni, że choć w kinie blockbusterowym dochodzi do rozrostu spektaklu, to jednak nadal realizuje ono podstawowe standardy kina klasycznego Hollywood, na czele z zachowaniem zasady segmentacji filmu na pięć podstawowych części, odpowiadajacych kolejnym etapom rozwoju spójnie ukształtowanej historii ${ }^{5}$. Jak dowodzi Bordwell, opowieść zawsze będzie obecna w kinie hollywoodzkim, albowiem nie da się kręcić filmów bazujących na samej akcji. Związane jest to z kilkoma okolicznościami, z których warto przywołać dwie najważniejsze. Po pierwsze, filmy z zawartościa czystej akcji oglądałaby bardzo waska grupa

${ }^{3}$ Th. Elsaesser, op. cit., s. 207.

${ }^{4}$ Justin Wyatt, High Concept. Movies and Marketing in Hollywood, Austin 1994, s. 8-15.

${ }^{5}$ Kristin Thompson, Storytelling in the New Hollywood. Understanding Classical Narrative Technique, Cambridge, MA 1999, s. 21-44. 
entuzjastów scen walki i pokazów pirotechnicznych, co stoi w sprzeczności z celem, jaki wyznaczaja sobie hollywoodzcy producenci, a więc pozyskaniem jak największej rzeszy widzów. Jego realizacja możliwa jest tylko wówczas, gdy film wzbogacony zostanie o takie elementy, jak chociażby konstytutywny dla kina klasycznego Hollywood watek romansowy, posiadajacy potencjał przyciagnięcia do kin żeńskiej części publiczności. Po drugie, produkcja spektakularnych sekwencji jest niezwykle czasochłonna i kosztowna, co sprawia, że w filmach zawsze będzie więcej kameralnych scen dialogowych. Nie ma natomiast lepszego sposobu na sensowne połaczenie tych ostatnich w spójną całość od wplecenia ich w szerszą opowieść dotyczacą działań protagonistów, posiadających wyraziste cele i motywacje ${ }^{6}$. Uzupełnieniem dla rozważań Bordwella i Thompson sa liczne analizy Geoffa Kinga, który wykazuje, że blockbusterowy spektakl nie jest zjawiskiem nowym. Istniał on także w erze kina klasycznego Hollywood i zarówno wtedy, jak i dzisiaj, świetnie służy celom narracyjnym. Jak wykazuje King, spektakularne sekwencje w kinie hollywoodzkim sa zazwyczaj powiązane z głównymi punktami zwrotnymi opowieści, zaś ich struktura na poziomie sjużetu bardzo często podporządkowana jest wymogom eksponowania losu bohaterów aniżeli epatowaniu widza czysto wizualna atrakcją ${ }^{7}$.

Swego rodzaju przypis do argumentacji Bordwella oraz Thompson stanowi „interpretacja zweryfikowanej historycznej ciagłości”. Jej czołowym wyrazicielem jest Rick Altman, który przyznaje, że kino blockbusterowe stanowi przedłużenie tradycji klasycznego kina hollywoodzkiego, jednak owa tradycję należy, jego zdaniem, postrzegać w szerszy sposób niż czynią to czołowi przedstawiciele neoformalizmu. Jak dowodzi Altman, w złotej erze Hollywood powstawały nie tylko filmy o spójnej, pięcioczęściowej strukturze sjużetu, ale także obrazy, które albo tak jak musical przedkładały poziom paradygmatyczny nad poziom syntagmatyczny, albo tak jak kino przygodowe bazowały na bardziej luźnym, epizodycznym ukształtowaniu fikcjonalnego materiału. W tym drugim przypadku Altman, a za nim Christine Gledhill, wskazuja na ciagłość, jaka zachodzi pomiędzy kinem hollywoodzkim a tradycją melodramatu teatralnego (melodrama $)^{8}$, uzupełniajac tym samym Bordwellowska liste pozafilmowych antenatów kina klasycznego, na której figuruja dobrze skrojony dramat dziewiętnastowieczny (well-made play) oraz nowela (short story).

W obliczu tak wielu - często wykluczajacych się wzajemnie - interpretacji, próba krótkiej charakterystyki kina blockbusterowego, na jaka pozwalaja rozmiary tego tekstu, wydaje się zadaniem karkołomnym. Z pewnościa nie da się tutaj wejść $\mathrm{w}$ głębszą dyskusję z reprezentantami poszczególnych stanowisk, a tym bardziej przeanalizować wszystkie poruszane przez nich kwestie. Dlatego też w poszukiwaniu kluczowych wyznaczników paradygmatu

${ }^{6}$ David Bordwell, The Way Hollywood Tells It. Story and Style in Modern Movies, BerkeleyLos Angeles-London 2006, s. 106-107.

${ }^{7}$ Geoff King, New Hollywood Cinema. An Introduction, New York 2002, s. 201-208.

${ }^{8}$ Por. Rick Altman, Dickens, Griffith, and Film Theory Today, [w:] Classical Hollywood Narrative. The Paradigm Wars, ed. Jane Gaines, Durham, NC 1992; Christine Gledhill, Rethinking Genre, [w:] Linda Williams, Christine Gledhill, Reinventing Film Studies, London 2000. 
współczesnego kina blockbusterowego postanowiłem zawęzić krag tematyczny moich rozważań do obszaru narracyjnego ukształtowania tekstu filmowego. Inaczej niż w przypadku opisów Bordwella czy Thompson, nie interesuja mnie tutaj całościowe struktury, w jakie wpisany jest spektakl, ale sekwencje spektakularne same w sobie. Innymi słowy, problem blockbusterowego spektaklu pragnę rozważyć wyłącznie na poziomie mikronarracji. Za każdym razem, gdy będzie to uzasadnione z punktu widzenia logiki mojego wywodu, postaram się odnieść do wybranych problemów stawianych przez cztery wyodrębnione przeze mnie szkoły interpretacji współczesnego kina blockbusterowego.

\section{$* * *$}

Nie ma chyba lepszego przykładu na to, co można by nazwać blockbusterowym spektaklem najwyższej próby, aniżeli niezwykle fantazyjna, trwająca ponad dziesięć minut sekwencja z remake'u King Konga w reżyserii Petera Jacksona, która przypada na sam środek filmu. Właśnie w tym momencie głównej bohaterce filmu, Ann Darrow, niedługo po tym, jak została złożona w ofierze Kongowi, udaje się uciec z rąk (a raczej łap) potwora. Bardzo szybko okazuje się jednak, że odzyskana przez nią wolność w realiach dzikiej puszczy jest istnym przekleństwem. Bezbronna Ann staje się bowiem smakowitym kaskiem dla kolejnych wygłodniałych monstrów, na czele z czterema tyranozaurami. Oczywiście w ostatnim momencie na ratunek osaczonej zewsząd przez krwiożercze bestie bohaterce przychodzi Kong. Nie oznacza to wszakże, że Ann może czuć sie już zupełnie bezpieczna. W ferworze walki Kong razem z tyranozaurami, osuwa się w wypełnioną lianami rozpadlinę, wypuszczając ze swych łap przerażona Ann. Przez kolejnych kilka minut widz obserwuje taniec zawieszonej nad przepaścią bohaterki, wokół której krążą bestie z rozwartymi paszczami. Mimo że każdy z tyranozaurów ma kilka okazji na skonsumowanie ofiary, co rusz od tragicznego końca Ann ratuje to, że spada w dół na kolejna lianę. Ta niezwykle barwna i brawurowa sekwencja mogłaby trwać w nieskończoność, gdyby nie fakt, że rozpadlina liczy sobie zaledwie kilkadziesiąt metrów. W efekcie zarówno Ann, jak i Kong wraz z atakujacymi ich tyranozaurami ląduja na ziemi, gdzie dochodzi do ostatecznego pojedynku pomiędzy wielka małpa a prehistorycznymi bestiami. Tylko ze względu na czysta formalność dodam, że zarówno Kong, jak i Ann także z tej opresji wychodzą cało i zdrowo.

Bordwell i Thompson, analizujac tę sekwencję, staraliby się zapewne wykazać, że aczkolwiek jest ona nieco za długa z punktu widzenia pełnionych przez nia funkcji narracyjnych, to jednak jej ogólna wymowa ma decydujace znaczenie dla rozwoju całej opowieści. Wszak to tu po raz pierwszy zawiazuje się bliższa relacja pomiędzy Ann a wielka małpą. Obserwując jak Kong z narażeniem własnego życia wielokrotnie broni ja przed atakami tyranozaurów, bezbronna bohaterka uświadamia sobie, że w tej bestii, kierującej się w pierwszym rzędzie zwierzęcymi instynktami, drzemią ogromne pokłady uczuć o typowo ludzkim charakterze. Jednak w tej strategii analitycznej neoformalistów, dążącej do każdorazowego wpisywania spektakularnych sekwencji w szersze 
struktury opowieści, tkwi pewien szkopuł. Otóż traca oni z pola widzenia sam spektakl wraz z jego specyficznymi właściwościami. Zazwyczaj dzieje się tak na skutek sprowadzenia całego problemu do dość powierzchownych wytłumaczeń, jak to podane przez Bordwella w książce The Way Hollywood Tells It:

[...] długość niektórych sekwencji akcji nie jest uzasadniona ich rolą w posuwaniu do przodu albo wzbogacaniu głównej historii, tak jak w przypadku sceny pościgu Humvee w Twierdzy (1996), w której narracyjna ekonomia złożona zostaje na ołtarzu chwilowych dreszczy emocji. Ale - taka już jest natura opowieści - każde wydarzenie w prezentowanej historii może zostać rozciagnięte do dowolnej długości; dowodem na to niech będą nie mające końca rozmowy w niektórych europejskich filmach ${ }^{9}$.

Przywołuje ten fragment rozważań Bordwella, gdyż jest on najlepszym przykładem analitycznej niekonsekwencji słynnego neoformalisty. Z jednej strony, bardzo często wykazuje on, że spektakl i klasyczna opowieść nie sa wykluczającymi się fenomenami, z drugiej opisuje spektakl w kategoriach strategii narracyjnych typowych dla paradygmatu kina artystycznego, który zgodnie z jego teoretycznym opisem czterech podstawowych form filmu fikcji stoi w zasadniczej opozycji do paradygmatu kina klasycznego. Owa niechęć do pogłębionych rozważań nad samą natura spektaklu jest o tyle zastanawiająca, że Thompson już w latach siedemdziesiątych zaproponowała nowy sposób analizy filmów, który odchodzi od strategii przypisywania wszystkim elementom filmu funkcji i znaczeń odnoszacych się do prezentowanej na ekranie opowieści. Posiłkując się miedzy innymi koncepcja „trzeciego sensu” Rolanda Barthesa, w artykule pt. The Concept of Cinematic Excess wykazała, że w filmie oprócz elementów służących konstrukcji fikcjonalnej diegesis istnieją także elementy nakierowujące uwagę widza na samą materię filmu. Co więcej, nawet elementy, które zasadniczo maja swój udział w posuwaniu historii do przodu oraz służą wzbogacaniu jej o dodatkowe sensy, poprzez takie rozwiązania jak chociażby ich nieustanne powtarzanie moga wprowadzić odbiorce w stan kontemplacji nad czysto fizykalna podstawą filmowego przedstawienia, które jawi mu sie jako nadmiar (excess) $)^{10}$. Majac w pamięci te ostatnie uwagi Thompson, postaram się wykazać, że głównym zadaniem przywołanej przeze mnie sekwencji z filmu King Kong nie jest wzbogacenie opowieści o dodatkowe elementy znaczeniowe, ale że ma ona do spełnienia zupełnie inne funkcje, charakterystyczne wyłącznie dla kina blockbusterowego.

Zgodnie z zaproponowaną przez Noëla Carrolla teorią narracji erotetycznej, która, jego zdaniem, charakteryzuje wszystkie fabularne utwory kultury masowej, to, że ciag prezentowanych w utworach popularnych wydarzeń układa się w pewna całość, nie jest zasługa działania relacji przyczynowo-skutkowej, ale tego, że „sytuacje i wydarzenia pojawiajace się w utworze wcześniej mają się tak do scen i wydarzeń po nich następujących, jak pytania do odpowiedzi"11. W taka konstrukcje tekstu wpisany jest zatem schemat jego odbioru: widz w toku ogladania filmu stawia wiele pytań, by następnie, w oparciu o informacje zawarte

\footnotetext{
${ }^{9}$ D. Bordwell, The Way..., s. 105.

${ }^{10}$ Kristin Thompson, The Concept of Cinematic Excess, "Ciné-Tracts" 1977, nr 2, s. 54-59.

${ }^{11}$ Noël Carroll, Filozofia horroru, przeł. Mirosław Przylipiak, Gdańsk 2004, s. 219.
} 
w poszczególnych elementach sjużetu, odnaleźć na nie odpowiedzi. Oczywiście najbardziej wyrazistym przykładem utworów z narracja erotetyczna sa kryminały, w których „morderstwo jest powodem pytania «kto zabił?». Odpowiedzi na nie dostarczaja kolejne sceny w formie poszlak i przesłanek. Te zaś we fragmencie końcowym, na przykład w podsumowującym monologu detektywa, składaja się na odpowiedź" 12 . Co istotne z punktu widzenia tej analizy dotyczacej zaledwie fragmentu filmu King Kong, wskazany przez Carrolla schemat narracyjny może działać zarówno w wymiarze makro (cały utwór), jak i w wymiarze mikro (dwie lub trzy konkretne sceny czy też jedna dłuższa sekwencja), przy czym na poziomie mikro $\mathrm{w}$ gre wchodzi nie tyle strategia budowania u widza zaciekawienia długofalowego, ile krótkotrwałego napięcia związanego z chwilową niepewnością o los głównego bohatera. Nie zmienia to jednak faktu, że także w tym przypadku utwór prowokuje widza do stawiania pytań, a następnie podsuwa mu ciag wskazówek, prowadzacych do ostatecznych odpowiedzi.

Bez watpienia, najbardziej rozpowszechniona strategia budowania u widza stanu niepewności i zaciekawienia w wymiarze mikro jest suspens (choć może być on także wykorzystany w wymiarze makro). Jak pisze Carroll: „suspens w utworach fikcjonalnych pojawia się, gdy rozwiąanie moralnie słuszne (w ramach wartości obowiązujących w fikcyjnym świecie) jest mniej prawdopodobne (lub w najlepszym razie tak samo prawdopodobne) niż rozwiązanie moralnie naganne"13. Doskonały przykład ilustrujacy tę definicję stanowi sekwencja z filmu Nieznajomi z pociagu (Strangers on the Train, 1951), w której szalony Bruno zabija żonę poznanego przypadkiem tenisisty, w nadziei na to, że ten w ramach rewanżu pozbawi życia jego ojca. Scena trwa kilka minut i składa się z dwóch zasadniczych części: śledzenia ofiary, a następnie jej zabójstwa. Pierwsza część pełni dwie funkcje: ukazuje widzowi determinację Bruno, a także jego przewage nad ofiara. Jeżeli chodzi o te druga kwestie, to kluczowe znaczenie ma scena, w której Bruno wygrywa konkurs uderzenia młotem; za jej pomoca Hitchcock sugeruje widzowi, że oprawca jest bardzo silny i w konfrontacji z nim ofiara nie ma najmniejszych szans. Jak nietrudno zatem zauważyć, u podstaw suspensu stoi ciag pytań i odpowiedzi o charakterze antycypacyjnym. Na początku przywołanej przeze mnie sekwencji z filmu Nieznajomi z pociagu widz nie jest jeszcze pewien rozwiązania. Wstępne pytanie brzmi: czy Bruno zabije bohaterkę? Jednak z czasem nabieramy pewności, że jest wyraźnie zdeterminowany, aby to uczynić. Rodzi się zatem nowe pytanie: czy bohaterka zginie? Scena konkursu uderzenia młotem podpowiada, że rozwiązanie moralnie słusznie jest mniej prawdopodobne. Teraz rodzi się zatem ostatnie pytanie: czy zabójcy uda się znaleźć odpowiednia okazję do zaatakowania ofiary oraz kiedy do tego dojdzie? Suspens uznać można zatem za kwintesencję klasycznego kina hollywoodzkiego, które zgodnie z opisem Davida Bordwella, zorientowane jest na przyszłośćc ${ }^{14}$. Widz oglądajacy film Nieznajomi z pociagu ma nieustannie zadawać sobie pytania, o to co stanie się za chwilę, nie zaś koncentrować się na „tu

\footnotetext{
12 Ibidem.

${ }^{13}$ Ibidem, s. 230-231.

${ }^{14}$ David Bordwell, Narration in the Fiction Film, Madison 1985, s. 165.
} 
i teraz" albo na przeszłości. Każda scena, a nawet jej części składowe takie jak pojedyncze ujęcie, nie są ważne same w sobie, ale poprzez to, że rodzą u widza kolejne pytania, stanowia pomost do kolejnych części filmu.

Warto jednak zwrócić uwage, że dla stworzenia udanego suspensu decydujace znaczenie ma przestrzeganie zasad narracyjnej ekonomii. Chodzi o to, że suspensu nie da się rozciagać w nieskończoność, ponieważ widz bardzo szybko przestanie odczuwać zaciekawienie i niepewność. Zauważmy, że momencie, gdy Hitchcock zaszczepił już u widza pytanie, o to kiedy Bruno zabije ofiare, pozwala on sobie na pewny rodzaj gry $\mathrm{z}$ widzem. W scenie majacej miejsce w tunelu dla zakochanych, poprzez sprytne połączenie ze soba w jednym z ujęć warstwy wizualnej (cień łodzi, w której siedzi ofiara oraz nakładający się na niego cień łodzi Bruno) oraz dźwiękowej (krzyk kobiety), Hitchcock przez ułamek sekundy sugeruje widzowi, że właśnie w tym momencie doszło do zabójstwa. Za chwile pojawia się jednak kolejne ujęcie, które prezentuje bohaterke całą i zdrowa, zaś jej krzyk okazuje się być reakcją na zaczepki jednego z towarzyszących jej przyjaciół. Hitchcock w niezwykle przemyślny sposób daje tu zatem widzowi przedsmak tego, co zdarzy się za chwilę. Rozwiązanie takie jest niezwykle ekscytujace, ponieważ zaostrza u widza będący podstawą odbiorczej przyjemności stan niepewności i zaciekawienia. Gdyby jednak Hitchcock pozwolił sobie na tego typu gre z widzem jeszcze kilka razy, widz bez watpienia szybko przyjąłby wobec prezentowanych wydarzeń postawę zdystansowania. Pytanie: „kiedy to się stanie?” z miejsca przerodziłoby się w pytanie: ,jak to się stanie?" Tym samym widz przestałby się interesować tym, co się wydarzy za chwilę, a coraz bardziej zwracałby uwage na to, co dzieje się w chwili obecnej. Orientacja filmu na przyszłość ustąpiłaby miejsca orientacji na teraźniejszość, powodujacc, że widz zacząłby koncentrować się na samej materii filmu, a przez to dostrzegać opisany przez Kristin Thompson nadmiar. Oczywiście Hitchcock jako mistrz suspensu nigdy nie pozwoliłby sobie na tego typu rozwiazanie. Konsekwencji zbyt długo przeciaganego suspensu nie omieszkał jednak ukazać słynny akolita autora Psychozy, Brian De Palma w filmie Świadek mimo woli (Body Double, 1984). W scenie morderstwa podglądanej przez głównego bohatera kobiety, znany ze stylistycznej ekstrawagancji reżyser w nieskończoność mnoży przeszkody, stające na drodze zabójcy (najpierw oprawca w zadziwiajacy sposób traci przytomność po lekkim uderzeniu go przez ofiare w twarz, a następnie, gdy już ma zabić bohaterkę za pomoca wiertarki, ta w ostatnim momencie się wyłącza, ponieważ jej kabel zasilający wypadł z gniazdka). W efekcie widz bardzo szybko przestaje zastanawiać się nad losem bohaterki, a zaczyna czerpać przyjemność z obserwowania coraz bardziej wymyślnych sposobów na przedłużenie życia ofiary. Nie należy przez to jednak wyciagać wniosku, że chwyt rozbrojenia suspensu stosowany jest tylko przez dążace do obnażania klasycznych konwencji kino postmodernistyczne. Tak naprawdę sięgano po niego już w złotej erze Hollywood. Najlepszym na to dowodem jest film Młody Sherlock Holmes (Sherlock Jr., 1924) i pochodząca z niego słynna scena nieudanej próby zabójstwa postaci granej przez Bustera Keatona za pomoca bomby ukrytej w bilardowej bili. Oczywiście tutaj motywacja, stojaca 
za rozciagnięciem struktury suspensu do granic wytrzymałości, ma charakter transtekstualny. Jak słusznie zauważają Steve Neal oraz Frank Krutnik, jednym z kluczowych narzędzi komedii jest suspens ${ }^{15}$. Jednak inaczej niż w kinie sensacyjnym, poprzez sprowadzenie jego logiki do absurdu, a także zwieńczenie całej sytuacji szczęśliwym zakończeniem, suspens komediowy ma widza bawić, a nie trzymać w napięciu. Nie zmienia to faktu, że na poziomie czysto tekstualnym struktura sceny z filmu Młody Sherlock Holmes niczym nie różni się od ukształtowania sceny z filmu Świadek mimo woli. W obu mamy bowiem do czynienia $\mathrm{z}$ nieustannym mnożeniem kolejnych sytuacji, odciagających $\mathrm{w}$ czasie finałowe rozwiązanie.

Nie inaczej rzecz się ma ze stanowiąca punkt wyjścia do przedstawionych rozważań sekwencja z Jacksonowskiego King Konga. Zauważmy, że chociaż w punkcie wyjścia pojawia się element inicjujący suspens, a więc pytanie „czy Ann przeżyje?", to jednak bardzo szybko film wymyka się logice opowiadania zarysowanej przez Carrolla. Wiazże się to z faktem, że oglądajacy go widz po pewnym czasie zapomina o poczatkowym pytaniu, a raczej staje sie ono dla niego nieistotne. Dzieje się tak dlatego, że w sytuacji gdy głównej bohaterce filmu udaje się kilkanaście razy z rzędu ujść niechybnej śmierci, odbiorca traci zainteresowanie jej losem, a jego uwage przyciaga czysta zdarzeniowość oraz audiowizualna atrakcyjność kolejnych ujęć. Także i tu widz przestaje zatem koncentrować się na tym co nastapi za chwile, a zaczyna zwracać uwagę na to, co „tu i teraz”, na czysta materię filmu. Oczywiście, rodzi się w tym miejscu pytanie: czemu właściwie taka strategia służy? Jak już zostało to wykazane wcześniej, zarówno w przypadku filmu Młody Sherlock Holmes, jak i Świadka mimo woli, nietrudno wskazać na motywację, stojąca za zabiegiem rozciagania suspensu. W pierwszym przypadku stanowia ja gatunkowe konwencje komedii, w drugim postmodernistyczna, mocno ironiczna gra z klasycznymi schematami kina hollywoodzkiego. Odnoszac się do klasyfikacji motywacji Davida Bordwella, można powiedzieć, że z jednej strony mamy do czynienia z motywacja transtekstualna, z drugiej z motywacja artystyczna ${ }^{16}$. Jaka motywacja stoi jednak za zabiegiem rozciagniętego suspensu w spektakularnej sekwencji z filmu King Kong?

Bordwell twierdzi, że spektakl także stanowi pochodna motywacji artystycznej. Odwołuje się zreszta do niego, gdy przychodzi mu wskazać na ślady tej motywacji w tradycji kina klasycznego. Oto co pisze w książce Narration in the Fiction Film:

[...] artystyczna motywacja - posługująca się elementem, którego obecność znajduje uzasadnienie w nim samym - nie jest rzeczą nieznaną klasycznemu filmowi. Moment spektaklu lub technicznej wirtuozerii, wtracane w musicalu numery taneczno-muzyczne czy komiczne interludia: kino hollywoodzkie sporadycznie dopuszcza możliwość czystego zaabsorbowania nim samym jako medium ${ }^{17}$.

${ }^{15}$ Steve Neal, Frank Krutnik, Popular Film and Television Comedy, London-New York 1990, s. $33-42$.

${ }^{16}$ D. Bordwell, Narration..., s. 36.

${ }^{17}$ Ibidem, s. 164. 
Oczywiście w pierwszym rzędzie należy Bordwellowi wytknąć fakt, że $\mathrm{w}$ ramach motywacji artystycznej wymienia on elementy podlegajace raczej działaniu motywacji gatunkowej (numery muzyczno-taneczne w musicalu oraz zabawne interludia w komedii). Jednak dla naszego wywodu najważniejsza jest kwestia przypisania spektaklu do motywacji artystycznej. Biorac pod uwage, że Bordwell zakłada ciagłość pomiędzy kinem klasycznego Hollywood a kinem współczesnym (w tym blockbusterowym), uznać należy, że obecność niezwykle długiej, spektakularnej sekwencji w King Kongu także uzasadnia motywacja artystyczna. Jak jednak dowiodłem wcześniej, z taka sytuacja mamy raczej do czynienia w postmodernistycznym, samoświadomym filmie Briana de Palmy, gdzie rozciagnięcie suspensu służy obnażeniu konwencjonalnego charakteru fikcji filmowej, wprowadzajac widza w, jak ująłby to Piotr Sitarski, „erudycyjny tryb odbioru"18. Wydaje się zatem, że dla pociagającego za soba eskalacje audiowizualnego spektaklu rozciagnięcia suspensu w King Kongu należy poszukać odmiennego wytłumaczenia.

Cały problem Bordwella polega na tym, że przy opisie spektaklu traci on z oczu jeszcze jedna motywację, która mogłaby uzasadniać jego pojawienie się w sjużecie. Podobnie jak motywacja transtekstualna ma ona charakter pozatekstowy, odnosi się jednak nie do aktualizowanej przez widza w trakcie odbioru filmu znajomości konwencji kina klasycznego, ale do samej sytuacji odbioru filmu. Motywację tę określę tutaj mianem motywacji dyspozytywowej. Spektakularne sekwencje od samego początku służyły w kinie hollywoodzkim do podkreślenia potegi i siły kinematograficznego medium. W sposób szczególny owa tendencja dała o sobie znać w latach pięćdziesiątych, gdy kino hollywoodzkie zmuszone zostało do konkurencji z telewizja.. Jej pojawienie się zrodziło konieczność znalezienia nowego sposobu na przyciagniecie widzów do kin. Lekiem na całe zło miał być, zdaniem szefów wielkich wytwórni, kinowy obraz, który dzięki temu, że jest kolorowy i ma ogromne rozmiary, stanowi realna konkurencje dla niewielkiego, czarno-białego ekranu telewizora. Stąd w latach pięćdziesiątych i sześćdziesiątych mamy do czynienia z wysypem epickich filmów o tematyce historycznej i biblijnej, które to gatunki już w erze kina niemego dostarczały dobrego pretekstu do wyeksponowania wizualnej potęi kina poprzez spektakl, a także wprowadzeniem niezliczonej ilości formatów szerokoekranowych, majaccych dodać owemu spektaklowi nowej jakości. Przedłużeniem tej strategii oczarowania widza wyjątkowymi warunkami projekcji kinowej są także współczesne rozwiązania w rodzaju ogromnych ekranów w kinach IMAX, w których swe otwarcie maja najważniejsze blockbustery sezonu.

A zatem zarówno spektakl w takim filmie jak Aleksander Wielki (Alexander the Great) z roku 1956 (pamiętne sceny bitew), jak i spektakl w King Kongu, zawdzięczaja swa obecność pozatekstualnej motywacji dyspozytywowej, nie zaś wynikajacej ze specyfiki danego tekstu motywacji artystycznej. Bordwell ma więc w pewnym sensie rację, mówiąc, że kino blockbusterowe

${ }^{18}$ Piotr Sitarski, Teoria autorska a nowe sposoby istnienia dzieta filmowego, [w:] Kino po kinie, red. Andrzej Gwóźdź, Warszawa 2010, s. 263. 
stanowi przedłużenie tradycji kina klasycznego Hollywood. Problem w tym, że owej ciagłości doszukiwać należy się nie w dominacji opowieści nad wszystkimi elementami filmu, ale właśnie w umotywowanej szczególnymi warunkami projekcji samowystarczalności spektaklu służącego prezentacji audiowizualnej potęgi kina, która objawia się zarówno w epickich filmach z lat pięćdziesiątych, jak i we współczesnych blockbusterach.

Pomimo tej wspólnej filmom Aleksander Wielki oraz King Kong motywacji dyspozytywowej, nie należy jednak stracić z oczu zasadniczej różnicy, jaka zachodzi pomiędzy zawartymi w nich rodzajami spektaklu. Odwołując się do klasyfikacji Tomasza Kłysa, spektakularność tego pierwszego filmu powiązać należy z kategorią spektaklu teatralno-malarskiego, bazujacego na przepychu inscenizacyjnym, a także rozbudowanej i skomplikowanej mise-en-scène (pełne statystów sceny walk zdjęte w totalnych planach eksponujacych bogactwo scenografii bądź też olśniewające piękno pejzażu), podczas gdy spektakularności filmu w reżyserii Petera Jacksona przypisać należy raczej wyznaczniki spektaklu kinematograficznego, czerpiącego swa siłę z czysto technologicznych możliwości medium, na czele z cyfrowymi efektami specjalnymi ${ }^{19}$. Ta różnica jest o tyle znacząca, że wiedzie nas do problemu istnienia we współczesnym kinie blockbusterowym jeszcze jednej motywacji uzasadniajacej dominujaca rolę spektaklu. O ile jednak wprowadzona przeze mnie wcześniej motywacja dyspozytywowa uzasadnia samą obecność spektaklu, o tyle ta druga, nazwijmy ja motywacja paratekstualna, prowadzi do jego rozrostu.

Jak nietrudno się domyślić, motywacja paratekstualna jest ściśle powiązana $\mathrm{z}$ fenomenem obudowywania tekstów filmowych niemającymi końca tekstami pobocznymi, takimi jak różnego rodzaju gadżety, płyty z muzyka, gry komputerowe, parki rozrywki, ale także krótkie filmy dokumentalne (tzw. making-of) czy też komentarze twórców, które dołączane są do wydań filmów na DVD albo udostępniane za pomoca stron internetowych. Na znaczenie tej pierwszej grupy paratekstów szczególną uwage zwracaja zwolennicy „interpretacji historycznego zerwania”. Justin Wyatt dowodzi na przykład, że wpisanie filmu w szerszy kontekst systemu rozrywkowego pozbawia go statusu tekstu samowystarczalnego, zaś na poziomie wewnętrznej struktury prowadzi do jego fragmentaryzacji (tutaj szczególna uwage przykłada on do opisu typowych dla kina high concept na poły teledyskowych scen, służaccych promocji napisanych na potrzeby danego filmu piosenek) ${ }^{20}$. Dla mnie bardziej istotne znaczenie maja jednak parateksty takie jak making-ofs oraz komentarze twórców. Ich główna funkcja jest dostarczenie widzowi wiedzy o tym, jak wyglądał proces realizacji najbardziej widowiskowych scen i sekwencji. Najlepszego materiału do tego typu paratekstów dostarcza oczywiście spektakl kinematograficzny. Spektakl teatralno-malarski dysponuje dość uboga paletą środków, które na dodatek na przestrzeni lat nie podlegały zasadniczym zmianom. Tymczasem spektakl kinematograficzny, szczególnie na obszarze cyfrowych efektów specjalnych, jest

19 Tomasz Kłys, Film fikcji $i$ jego dominanty, Warszawa 1999, s. 161.

${ }^{20}$ J. Wyatt, op. cit., s. 36-44. 
fenomenem niezwykle dynamicznym, poddawanym nieustannym udoskonaleniom dzięki ciagłemu postępowi technologicznemu. Oczywiście nie chcę przez to powiedzieć, że obecna dominacja spektaklu kinematograficznego we współczesnym kinie jest pochodna pojawienia się nieobecnej kiedyś formuły paratekstów w rodzaju making-of. Tego rodzaju spektakl istniał także wcześniej, chociażby w postaci olśniewającej animacji poklatkowej autorstwa Willisa O’Briena w pierwotnej wersji King Konga z roku $1933^{21}$. Tak jak już wspomniałem wcześniej, motywacja paratekstualna wpływa raczej na rozrost tego typu spektaklu. Wszak im więcej spektakularnych sekwencji pojawi się w filmie albo im dłuższy będzie czas ich trwania, tym większą ilość komentarzy, czy też $m a-$ king-ofs będzie można na ich bazie wytworzyć, a następnie sprzedać w kolejnych kanałach dystrybucji. Analizowany przeze mnie film King Kong w reżyserii Petera Jacksona jest podręcznikowym przykładem tej strategii. W ramach dodatkowych okien jego eksploatacji, a więc kina domowego oraz Internetu, wytworzono ogromna ilość paratekstów o charakterze filmików dokumentujących poszczególne etapy produkcji filmu. Najpierw kilka odcinków tego cyklu udostępniono darmowo za pośrednictwem serwisu administrowanego przez fanów postaci King Konga (choć znając przebiegłość speców od marketingu można mieć uzasadnione podejrzenia, że serwis ten został wypreparowany specjalnie na cele promocji filmu), by następnie wydać je na dwupłytowym, wzbogaconym o dodatkowe kilkadziesiąt minut nowego materiału wydaniu DVD pod tytułem „King Kong”: Peter Jackson's Production Diaries. Analizowana przeze mnie sekwencja walki o życie Ann stanowi jeden z kluczowych tematów owych audiowizualnych dzienników. Najzabawniejsze jest jednak to, że przy okazji jej omawiania Peter Jackson zapewnia widza, że ze względu na swa fascynacje King Kongiem w reżyserii Meriana C. Coopera i Ernesta Schoedsacka robił wszystko, aby jak najwierniej oddać specyfikę oryginału, ani słowem nie zająkując się o tym, że w filmie z roku 1933 Kong walczy tylko z jednym tyranozaurem i zajmuje mu to nie dziesięć minut, ale zaledwie trzy.

Uzasadniony motywacją paratekstualną rozrost sekwencji z dużą ilością cyfrowych efektów specjalnych pociąga za sobą konsekwencje dwojakiego rodzaju. Po pierwsze, wpływa na strukture samego filmu. Po drugie, narzuca widzowi specyficzny tryb jego odbioru. Obie te kwestie w sposób niezwykle przenikliwy opisał Jürgen Trinks. Odwołując się do pierwszych filmów, w których na szeroka skalę zastosowano „komputerowe techniki przetwarzania obrazu”22, takich jak Terminator 2 czy Park Jurajski, Trinks zauważa, że wszystkie sekwencje z dominantą efektów specjalnych odchodzą od uporządkowania narracyjnego,

${ }^{21}$ Nieobecnością paratekstów nie powinno się także tłumaczyć faktu dominacji spektaklu teatralno-malarskiego w hollywoodzkim kinie lat pięćdziesiątych. Skłonność twórców do posługiwania się setkami statystów i gigantycznymi scenografiami wynikała wówczas raczej z tego, że na fali cięć finansowych w wielkich wytwórniach zlikwidowano dużą część działów efektów specjalnych. W konsekwencji jedynym sposobem na porażenie widza potęga kinowego obrazu było postawienie na monumentalność profilmowej inscenizacji.

${ }^{22}$ Jürgen Trinks, Seryjność jako podstawowy problem estetyki telewizji, [w:] Piękno $w$ sieci. Estetyka a nowe media, red. Krystyna Wilkoszewska, Kraków 1999, s.162. 
w którego centrum stoi opowieść i upodabniaja się do telewizyjnego strumienia. Jak pisze Trinks: „Podczas gdy rozczłonkowane następstwo obrazów lub elementów opowieści prowadzi do ukonstytuowania się przyjemnej, przyciagającej uwagę całości, to strumień obrazów nie prowadzi do takiej konstytucji. W opowieści można się spokojnie zanurzyć, uporządkowane następstwa zdarzeń zawsze daja poczucie możliwości utrzymania kontroli. Do strumienia nie można mieć w tym sensie zaufania. Aby nie dać się wchłonać przez jego brak rozczłonkowania albo uchronić się od nudy - potrzebne jest nastawienie badawcze i dystans. Strumień w mniejszym stopniu nadaje się do podziwiania niż badania. Zamiast bezpośredniego przeżycia potrzebny jest tu dystans, także po to, by móc sprostać wszelkim próbom losu, jakie przynosi strumień obrazów wśród bogactwa dostarczanych informacji”23. Opisane przez Trinksa nastawienie badacze i dystans odpowiada innemu, wyróżnionemu przez Piotra Sitarskiego, rodzajowi odbioru filmu w erze wzrostu znaczenia kina domowego, a mianowicie oglądaniu analitycznemu, w którego przypadku „przyjemność daje uświadomienie budowy tekstu filmowego" "24. Badacz spostrzegajacc, że zwykle making-ofs i komentarze twórców poświęcone sa efektom specjalnym, wykazuje przy okazji na różnice, jaka dzieli podejście dawnego widza do filmów w rodzaju King Konga z roku 1933 od podejścia widza współczesnego do jego remake'u w reżyserii Jacksona. „W nie tak dawnych jeszcze czasach efekty specjalne były okryte tajemnica nie tylko przed widzami, ale nawet przed innymi fachowcami, a pytanie «jak oni to zrobili?», należało do repertuaru typowych zachwytów kinowych. O przyjemności decydowały więc zagadka i cudowność" 25 .

Podsumowując rozważania nad kwestiami nowego typu postawy odbiorczej przyjmowanej przez widzów wobec kina blockbusterowego, należy zauważyć, że wielkie wytwórnie hollywoodzkie, posługując się strategia paratekstualnego obudowania filmów takimi dodatkami jak komentarze twórców oraz making-ofs, dokonuja instytucjonalizacji trybu odbioru, który kiedyś postulowała Kristin Thompson, zachęcając widzów i badaczy do zwrócenia uwagi na materialna stronę filmu, na drzemiący pod powierzchnią opowieści nadmiar. O ile jednak w przypadku postulatu Thompson, uchwycenie nadmiaru wymaga od widza autentycznego wysiłku, albowiem musi on wyzbyć się swych przyzwyczajeń do nadawania każdemu filmowemu elementowi znaczenia fabularnego, o tyle współczesnemu widzowi, oglądającemu making-ofs w domowym zaciszu, serwuje się łatwy w konsumpcji nadmiar w stylu fast food. Co więcej, także w trakcie odbioru kinowego nie musi on dokonywać zbytniego wysiłku, aby wejść w stan analitycznego nastawienia. Jak wykaże poniżej, sprzyjaja temu pewne charakterystyczne dla kina blockbusterowego rozwiązania w ukształtowaniu sjużetu.

Jak wspomniałem wcześniej, sekwencja z filmu Jacksona jest dużo dłuższa od analogicznej sekwencji zawartej w oryginalnej wersji King Konga. Ów czasowy rozrost spektaklu w remake'u z początku XXI wieku spowodowany jest rozmnożeniem bestii, z którymi przychodzi zmierzyć się Kongowi. Jednak sama

\footnotetext{
${ }^{23}$ Ibidem, s. 163.

${ }^{24}$ P. Sitarski, op. cit., s. 262.

${ }^{25}$ Ibidem.
} 
finałowa scena pojedynku wielkiej małpy z ostatnim pozostałym przy życiu tyranozaurem w wymiarze czasowym niewiele różni się od pierwowzoru. Nie oznacza to wszakże, że obie sceny są ze sobą identyczne. Pomimo powierzchownych podobieństw (np. żartobliwe zakończenie, w którym Kong, poruszając bezwładna szczęka dinozaura sprawdza, czy bestia nie żyje), struktura sjużetu filmu Jacksona wykazuje wyraźne odstępstwa od ukształtowania sjużetu obrazu Coopera i Schoedsacka. O ile w tym pierwszym filmie mamy do czynienia z duża ilością ujęć z punktu widzenia Ann, o tyle w obrazie z roku 1933 cała scena zdjeta zostaje w serii ujęć zrealizowanych za pomoca kamery obiektywnej ${ }^{26}$. Fakt ten wydaje się na pierwszy rzut oka paradoksalny. Skoro, jak chca tego chociażby zwolennicy „interpretacji zerwanej ciagłości”, współczesne kino blockbusterowe w przeciwieństwie do kina klasycznego spycha na plan drugi postać wraz z jej angażujacym widza emocjonalnie w film potencjałem, uzasadnionym wydawałoby się oczekiwanie, że to w oryginalnej wersji King Konga będziemy mieli do czynienia z dużą ilościa POV. Jak jednak słusznie zauważa Murray Smith, psychoanalityczne interpretacje modelu identyfikacji widza z postacia, które stoja $\mathrm{u}$ podstaw tego typu opinii, sa z gruntu nieprawdziwe. Zabieg POV nie może decydować o tym, że wczuwamy się w los jakiejś konkretnej postaci, albowiem $\mathrm{w}$ przeciętnym filmie hollywoodzkim stosowany jest on zarówno w odniesieniu do protagonistów, jak i antagonistów, a nawet postaci drugoplanowych. W efekcie, widz angażujacy się w film tylko w oparciu o ujęcia subiektywne, musiałby identyfikować się ze wszystkimi bohaterami, także tymi złymi np. z Jasonem w filmie Piatek 13-ego, którego sjużet w dużej mierze składa się z POV mordercy. Jak dowodzi Smith, to że współodczuwamy los postaci, jest wynikiem bardziej złożonego procesu poznawczo-afektywnego, na który wpływ mają różne składniki filmowej struktury ${ }^{27}$. Teoria Smitha, ze względu na swój komplementarny charakter, jest niezwykle skomplikowana, stąd też w moich rozważaniach ogranicze się do tych jej składników, które będa pomocne w analizie porównawczej finałowych scen walki obecnych w dwóch wersjach King Koga.

Smith, piszac o tzw. strukturze sympatii, wskazuje na trzy jej komponenty: rozpoznanie, współodczuwanie i nastawienie. Szczególnie ważny jest drugi z nich, a więc współodczuwanie. Za pomoca tego procesu widzowie „uzyskują

${ }^{26}$ Warto zwrócić uwagę, że w scenie z filmu z roku 1933 kilka razy pojawia się ujęcie patrzącej na walkę Konga Ann (pojawiaja się tu zatem dwa pierwsze, wskazane przez Edwarda Branigana, elementy frazy POV, a więc postać i spojrzenie), za każdym razem następuja po nich jednak ujęcia w planie totalnym, ukazujące zarówno zmagające się ze sobą bestie, jak i Ann, które ze względu na obecność w nich bohaterki nie mogą być uznane za wykonane z punktu jej widzenia. W filmie Coopera i Schoedsacka dochodzi zatem do zerwania zasady ciagłości montażowej opartej na zasadzie kierunku spojrzenia, co daje o sobie znać w momencie cięć montażowych, kiedy dochodzi do wyraźnego zgrzytu pomiędzy kolejnymi ujęciami. Tak ostentacyjne złamanie jednej z kluczowych konwencji klasycznego kina hollywoodzkiego wytłumaczyć należy najprawdopodobniej dążeniem twórców do pokazania maestrii, z jaką w filmie stosuje się różne rodzaje tylnej projekcji, umożliwiającej połaczenie odtworzonej przy pomocy animacji poklatkowej walki Konga z tyranozaurem z działaniami żywej aktorki.

${ }^{27}$ Jacek Ostaszewski, Film i poznanie. Wprowadzenie do kognitywnej teorii filmu, Kraków 1999, s. 156-157. 
dostęp do działań, myśli i uczuć postaci”"28. Co jednak najważniejsze, Smith podkreśla, że „ujęcie z punktu widzenia wcale nie odgrywa uprzywilejowanej roli przy umożliwianiu nam lepszego wglądu w stany postaci, jak zakłada większość modeli identyfikacji”29. Decydujace znaczenie dla zaistnienia stanu współodczuwania maja raczej „więź czasoprzestrzenna” oraz „dostęp subiektywny”. „Więź dotyczy sposobu, w jaki narracja zawęża się do opisu działań jednej postaci lub toczy się swobodniej po przestrzenno-czasowych kolejach losu dwóch lub więcej postaci. Dostęp subiektywny odnosi się do tego, jak dalece możemy wejrzeć w subiektywność postaci”30.

W świetle przedstawionych ustaleń, brak ujęć POV w klasycznej wersji King Konga nie jest już niczym zaskakującym. Wszak twórcy filmu moga wprowadzić widza w stan współodczuwania z bohaterka za pomocą innych środków. Czynia to, przede wszystkim umieszczajac postać bohaterki w pierwszym planie ujęcia, co powoduje, że walka dwóch bestii jawi się widzowi jedynie jako tło dla działań głównej postaci. Te zaś ze względu na swój niezwykle ekspresyjny charakter (nieustanne krzyki i wymachiwanie rękoma), dostarczaja widzowi łatwych wskazówek do odtworzenia stanu emocjonalnego Ann, który sprowadza się do bezgranicznego przerażenia całą sytuacją i lęku o własne życie. W połowie sceny twórcy starają się zresztą dowieść, że taki emocjonalny stan bohaterki jest w pełni uzasadniony. W tym celu prezentują widzowi sytuacje, w której uderzenie ogona tyranozaura prowadzi do przewrócenia się drzewa, na którym siedzi Ann. Tym samym staraja się zdynamizować akcję na pierwszym planie, tak aby nawet przez moment rozgrywająca się w tle widowiskowa walka dwóch bestii nie odciagnęła uwagi widza od losu bohaterki.

Jak tymczasem przedstawia się sjużet finałowej sceny walki Koga z tyranozaurem w filmie Jacksona? Wspomniałem już o tym, że dominująca rolę odgrywa w nim fraza POV. Co rusz mamy tu do czynienia z następstwem ujęć, w których najpierw widzimy wpatrujaca się w coś Ann, by potem zobaczyć przedmiot jej spojrzenia. Paradoksalnie jednak, to służące ponoć identyfikacji widza z postacią rozwiazanie prowadzi tak naprawdę do zdystansowania się widza wobec Ann, a tym samym całej prezentowanej na ekranie akcji. Bohaterka wypchnięta poza obszar walki, przestaje funkcjonować na zasadzie zaangażowanej w nia strony, przyjmujac w zamian rolę biernego obserwatora. W konsekwencji, inaczej niż bohaterce filmu z roku 1933, nie grozi jej żadne niebezpieczeństwo, które mogłoby spowodować, że widz będzie się przejmował jej losem.

Barry Langford zwraca uwagę, że owa figura wpatrującego się w spektakularna akcje bohatera stanowi jeden ze znaków rozpoznawczych współczesnego kina blockbusterowego. Za jej twórce i zarazem najbardziej oddanego promotora badacz uznaje Stevena Spielberga. W jego twórczości od samego początku pojawiają się postacie, które w kontakcie z niezwykłymi wydarzeniami wygenerowanymi za pomoca efektów specjalnych popadaja w stan zachwytu

${ }^{28}$ Ibidem, s. 161.

${ }^{29}$ Murray Smith, Zaangażowanie widza w postać, przeł. Jolanta Mach, [w:] Kognitywna teoria filmu: antologia przektadów, red. Jacek Ostaszewski, Kraków 1999, s. 221.

${ }^{30}$ Ibidem, s. 220-221 
bliskiego wzniosłości, objawiajacego się takimi fizycznymi cechami jak rozwarte szeroko usta oraz oczy („wow” response $)^{31}$. Postacie takie działaja na zasadzie wpisanych w tekst awatarów widzów, którzy powinni oddać się podobnemu stanowi kontemplacji. Jej przedmiotem ma być oczywiście wirtuozeria, z jaką twórcy wyczarowali niezwykłe obrazy, a więc, odwołując się do rozważań Thompson, materialna strona filmu, jego stylistyczny nadmiar. Uzasadnionym wydaje się zatem stwierdzenie, że w przypadku analizowanej sceny z filmu Jacksona mamy do czynienia z innym rodzajem POV aniżeli w przypadku POV sfunkcjonalizowanego narracyjnie. Zamiast wizualnej subiektywizacji w wariancie „fokalizacji” w gre wchodzi tu raczej typowa dla wczesnego kina atrakcji „okularyzacja”” Jak ujmuje to autorka tego rozróżnienia, Elżbieta Ostrowska, „w modelu narracji aktualizowanym w «kinie wizualnej atrakcji» (showing) subiektywizacją przestrzeni rządzi zasada okularyzacji (pokazanie, zademonstrowanie widzowi obiektu usytuowanego w danym segmencie przestrzeni w celu dostarczenia czystej przyjemności widzenia obiektu), podczas gdy w filmach konstytuujacych model «kina narracyjnej integralności» (telling) zachodzi proces fokalizacji, wskutek czego zmienia się zasadniczo funkcja opisywanego chwytu. Możliwość zobaczenia czegoś «oczami» filmowej postaci nie jest w tym przypadku źródłem «wizualnej przyjemności», ale wykorzystywana jest przede wszystkim jako środek dostarczenia widzowi wiedzy na temat fikcyjnego świata filmowego, co pozwala odbiorcy przewidzieć rozwój zachodzacych w nim wydarzeń" 32 . Także i w wypadku zastosowania frazy POV w wariancie „okularyzacji” zniesione zostaje zatem w kinie blockbusterowym zorientowanie filmu na przyszłość, co prowadzi do zwrócenia uwagi widza na to, co „tu i teraz”. Należy przy tym zauważyć, że owa strategia okularyzacji ma do odegrania szczególnie ważna rolę na poziomie odbioru kinowego filmu. Za jej pomoca twórcy zwracają bowiem uwage widzów na szczególnie wymyślne efekty specjalne, budzac u nich zaciekawienie tym, jak to wszystko zostało zrobione. Pochodna tego stanu zaciekawienia ma być oczywiście zakup wydania filmu na DVD, które zaopatrzone zostanie w odpowiednie materiały dokumentalne oraz komentarze twórców, odpowiadające na wszystkie pytania widza.

Można zatem powiedzieć, że w kinie blockbusterowym dochodzi do poważnej zmiany modelu odbioru filmu. O ile w kinie klasycznym, dominujaca postawa przyjmowana przez widza wobec świata fikcji jest zaangażowanie o charakterze mentalno-emocjonalnym, w przypadku współczesnych superprodukcji miejsce tej pierwszej zajmuje postawa daleko posuniętego zdystansowania o charakterze analitycznym. Nawet pomimo, że okularyzacja posiada potencjał wprowadzenia widza w stan kontemplacyjnego zachwytu, który uznać by można za namiastke emocjonalnego zaangażowania, to, jak słusznie zauważa opisujacy kwestie spektaklu z perspektywy antropologicznej John J. MacAloon, uczucie to szybko zostaje rozproszone przez postawę hiperrefleksywności. Badacz wykazuje, że w spektakl na poziomie jego metaprzekazu wpisane sa

\footnotetext{
${ }^{31}$ Barry Langford, Film Genre Hollywood and Beyond, Edinburgh 2005, s. 244-245.

${ }^{32}$ Elżbieta Ostrowska, Przestrzeń filmowa, Kraków 2000, s. 151.
} 
dwa kluczowe apele skierowane wprost do widza: „Nie musisz nic robić, tylko patrz” oraz „Podziwiaj, ale nie daj się zwieść”33. Oba te apele, co wykazała moja analiza, sa ze soba ściśle powiązane. Pierwszy skutkuje u odbiorcy stanem zdystansowania, będącego pochodna biernego oglądania (osiaga się to głównie poprzez rozciagnięcie spektaklu w czasie), drugi wywołuje u niego stan hiperrefleksywności (temu służy z kolei chwyt okularyzacji).

W tytule tego artykułu posługuje się sformułowaniem „wstęp do opisu współczesnego kina blockbusterowego". Wynika to z faktu, o którym wspominałem już wcześniej. W tekście o takiej objętości trudno zawrzeć wszystkie kwestie związane z charakterystyka kina blockbusterowego. Z punktu widzenia narratologii zabrakło tu z pewnościa rozważań nad strukturami makroopowiadania. Jak jednak zaznaczyłem na wstępie, jest to świadomie przyjęte przeze mnie samoograniczenie. Nie oznacza to oczywiście, że kwestie tego typu zupełnie mnie nie interesuja. W innym miejscu opisuje chociażby problem funkcjonalizacji w kinie blockbusterowym figury bohatera zbiorowego w filmach opartych na schemacie: „kto następny?”34. Na rozważenie zasługuje również kwestia poliferacji linii akcji we współczesnym kinie hollywoodzkim. Co prawda zabieg ten dotyczy szerszej grupy filmów aniżeli samo kino blockbusterowe, jednak w tym ostatnim spełnia on, jak mi się wydaje, ważną rolę przy eksponowaniu audiowizualnego spektaklu. W związku z ta kwestia, należałoby zreszta po raz kolejny zweryfikować ustalenia neoformalistów. Kristin Thompson w ksiazżce pt. Storytelling in The New Hollywood, zestawiajac ze soba takie filmy jak Ludzie z hotelu (Grand Hotel, 1932) oraz Ptonacy wieżwiec (The Towering Inferno, 1977), zdaje się bowiem sugerować, że tendencja do mnożenia wielu linii akcji jest tendencja typowa zarówno dla kina klasycznego, jak i współczesnego ${ }^{35}$. Badaczka przemilcza jednak fakt, że film Ludzie $z$ hotelu stanowi część krótkotrwałego cyklu z początku lat trzydziestych, którego cechą konstytutywna jest to, że we wchodzacych w jego skład obrazach występuje duża liczba znanych i popularnych w tamtym okresie aktorów, co służyć miało po części celom marketingowym wielkich wytwórni, pragnacych pochwalić się swoja „stajnia”, a przy okazji ugruntować system gwiazd. Tak naprawdę tylko w ramach dwóch gatunków o dość długim żywocie da się wskazać realizacje strategii mnożenia bohaterów oraz proliferacji linii akcji, a mianowicie w kinie wojennym oraz kinie przygodowym (jego przykładem jest analizowany przeze mnie King Kong Coopera). Oba te gatunki sa jednak przez neoformalistów rzadko opisywane, albowiem ich struktura odbiega od klasycznej pięcioaktowej segmentacji sjużetu. Stanowią one tymczasem istotną część tradycji kina klasycznego Hollywood i, na co wskazuje Rick Altman, to właśnie

${ }^{33}$ John J. MacAloon, Igrzyska Olimpijskie a teoria widowisk w społeczeństwach wspótczesnych, [w:] Rytuat, dramat, święto, spektakl. Wstęp do teorii widowiska kulturowego, red. J. J. MacAloon, Warszawa 2009, s. 401-409.

${ }^{34}$ Krzysztof Jajko, Jeżeli ginać to tylko $w$ grupie. Problem narracyjnego sfunkcjonalizowania motywu śmierci $w$ blockbusterach wykorzystujacych schemat bohatera zbiorowego, [w:] Śmierć w zwierciadle humanistyki, red. Dominika Gapska, Poznań 2013.

${ }^{35}$ K. Thompson, Storytelling..., s. 47-48. 
one powinny być brane pod uwage przy rozpatrywaniu ewentualnej ciagłości pomiędzy współczesnym kinem blockbusterowym a klasycznym kinem hollywoodzkim. Aczkolwiek postulaty Altmana wydaja się w pełni uzasadnione, wydaje się jednak, że w przypadku strategii posługiwania się kilkoma bohaterami, których losy prezentowane sa w osobnych liniach akcji, z wyraźna obecnościa tego rozwiązania mamy do czynienia dopiero w kinie współczesnym. Podczas gdy King Kong Coopera i Schoedsacka był w swych czasach wyjątkiem od reguły, King Kong Jacksona stanowi jej najlepszą egzemplifikację.

\section{Bibliografia}

Adamczak M., Globalne Hollywood, filmowa Europa i polskie kino po roku 1989, Gdańsk 2010.

Altman R., Dickens, Griffith, and Film Theory Today, [w:] Classical Hollywood Narrative. The Paradigm Wars, ed. Jane Gaines, Durham, NC 1992.

Bordwell D., Narration in the Fiction Film, Madison 1985.

Bordwell D., The Way Hollywood Tells It. Story and Style in Modern Movies, Berkeley-Los Angeles-London 2006.

Carroll N., Filozofia horroru, przeł.Mirosław Przylipiak, Gdańsk 2004.

De Vany A., Hollywood Economics: How Extreme Uncertainty Shapes the Film Industry, LondonNew York 2004.

Elsaesser Th., Discipline through Diegesis: The Rube Film Between "Atraction" and "Narrative Integration", [w:] Wanda Strauven, The Cinema of Attractions Reloaded, Amsterdam 2006.

Gledhill Ch., Rethinking Genre, [w:] Linda Williams, Christine Gledhill, Reinventing Film Studies, London 2000.

Hall Sh., Neale S., Epics, Spectacles and Blockbusters, Detroit 2010.

Jajko K., Jeżeli ginać to tylko w grupie. Problem narracyjnego sfunkcjonalizowania motywu śmierci w blockbusterach wykorzystujacych schemat bohatera zbiorowego, [w:] Śmierć w zwierciadle humanistyki, red. Dominika Gapska, Poznań 2013.

King G., New Hollywood Cinema. An Introduction, New York 2002.

Kłys T., Film fikcji i jego dominanty, Warszawa 1999.

Langford B., Film Genre Hollywood and Beyond, Edinburgh 2005.

MacAloon J. J., Igrzyska Olimpijskie a teoria widowisk w społeczeństwach wspótczesnych, [w:] Rytuat, dramat, święto, spektakl. Wstęp do teorii widowiska kulturowego, red. J. J. MacAloon, Warszawa 2009.

Murray Smith, Zaangażowanie widza w postać, przeł. Jolanta Mach, [w:] Kognitywna teoria filmu: antologia przektadów, red. Jacek Ostaszewski, Kraków 1999.

Neal S., Krutnik F., Popular Film and Television Comedy, London-New York 1990.

Ostaszewski J., Film i poznanie. Wprowadzenie do kognitywnej teorii filmu, Kraków 1999.

Ostrowska E., Przestrzeń filmowa, Kraków 2000.

Shatz Th., The Studio System and Conglomerate Hollywood, [w:] The Contemporary Hollywood Film Industry, eds. Paul McDonald, Janet Wasko, Hoboken, NJ 2008.

Sitarski P., Teoria autorska a nowe sposoby istnienia dzieta filmowego, [w:] Kino po kinie, red. Andrzej Gwóźdź, Warszawa 2010.

Thompson K., The Concept of Cinematic Excess, "Ciné-Tracts" 1977, No. 2.

Thompson K., Storytelling in the New Hollywood. Understanding Classical Narrative Technique, Cambridge, MA 1999.

Trinks J., Seryjność jako podstawowy problem estetyki telewizji, [w:] Piękno w sieci. Estetyka a nowe media, red. Krystyna Wilkoszewska, Kraków 1999.

Wyatt J., High Concept. Movies and Marketing in Hollywood, Austin 1994. 